\title{
Profitability of Carbon Sequestration in Western Rangelands of the United States
}

\author{
John P. Ritten, ${ }^{1}$ Christopher T. Bastian, ${ }^{2}$ and Benjamin S. Rashford ${ }^{1}$ \\ Authors are ${ }^{1}$ Assistant Professor and ${ }^{2}$ Associate Professor, Department of Agricultural and Applied Economics, University of Wyoming, Laramie, WY
} 82071, USA.

\begin{abstract}
Concerns over climate change have increased interest in carbon sequestration in agricultural lands. While the per-hectare carbon capture potential of rangelands is less than either cropland or forests, existing research suggests modest changes in carbon storage on rangelands can potentially alter the global carbon cycle. This paper examines the potential firm-level revenues from voluntary carbon offset programs, such as the Chicago Climate Exchange (CCX) Rangeland Soil Carbon Offset program. We estimate revenues for short-term voluntary offsets given historical prices and prices projected with potential cap-and-trade legislation. We also estimate revenues assuming 100-yr offsets are required to meet international sequestration standards. Simulation results indicate a relatively wide range of modest revenues from recent CCX contracts and carbon prices. The analysis suggests that recent carbon prices or low-end projected prices from cap-and-trade legislation are not likely to encourage producer participation. Medium and high carbon price projections for cap-and-trade legislation may make carbon sequestration a more attractive option for rangeland managers, but given potential requirements for projects to meet international guidelines for greenhouse gas offset projects, many issues remain before range managers may be interested in carbon sequestration as an enterprise.
\end{abstract}

\section{Resumen}

La preocupación sobre el cambio climático ha aumentado el interés en el secuestro de carbono en tierras de uso agropecuario. Mientras que el potencial de captura de carbono en pastizales es menor que en tierras agrícolas y bosques, investigaciones sugieren que cambios modestos en el almacén de carbono en pastizales potencialmente alteran el ciclo global del carbono. Este artículo examina el ingreso potencial a nivel de empresa en programas voluntarios para la compensación de carbono tales como el programa de Compensación de Carbono en Pastizales del Chicago Climate Exchange (CCX). Estimamos ingresos en el corto plazo por compensaciones voluntarias dado precios históricos y precios proyectados con potencial con legislación de tope y compra-venta. También estimamos ingresos asumiendo 100 años de compensación tal como es requerido para cumplir los estándares internacionales de captura. Resultados de simulaciones indican relativamente amplio margen de modestos ingresos de contratos recientes del CCX y precios del carbono. El análisis sugiere que los precios recientes del carbono o proyectos de menor importancia de la legislación tipo tope y compra-venta no tienen posibilidad de encontrar la participación de los productores. La proyección de precios medianos y altos del carbono de la legislación tope y compra-venta podría hacer más atractiva la opción de captura de carbono para los manejadores de pastizales pero, dado los requerimientos potenciales para proyectos que cumplan con los lineamientos internacionales para la compensación de proyectos de gases de efecto invernadero, muchos aspectos están presentes antes de que los manejadores de pastizales pudieran estar interesados en el secuestro de carbono a nivel empresarial.

Key Words: cap-and-trade, carbon storage, economic incentives, revenue

\section{INTRODUCTION}

Concerns over global climate change have increased interest in carbon sequestration on agricultural lands, including rangelands. Although there is relatively low per unit area sequestration potential on rangelands (Follett and Reed 2010), the magnitude of land area covered by rangelands suggests even modest changes in its carbon storage could alter the global carbon cycle (Schuman et al. 2002; Derner and Schuman 2007; Laca et al. 2010). Current estimates place global rangelands at 3.6 billion ha, and pastures and rangelands total nearly 239 million ha in the United States alone (Follett et al. 2001; Follett and Reed 2010; Sobecki et al. 2001). Increased soil organic

Correspondence: John P. Ritten, Dept of Agricultural and Applied Economics, University of Wyoming, Laramie, WY 82071, USA. Email: jritten@uwyo.edu

Manuscript received 20 December 2010; manuscript accepted 31 March 2012. carbon (SOC) in rangelands can also generate other environmental benefits, including improved soil quality, soil waterholding capacity, nutrient cycling, and reduced erosion (Derner and Schuman 2007).

Many countries, including the United States, are interested in promoting agricultural land management activities that sequester carbon to meet greenhouse gas (GHG) emission goals. Permit trading markets that provide incentives for agriculture to sequester carbon can efficiently reduce net atmospheric carbon (Feng et al. 2002); however, issues of economic feasibility (i.e., sufficient incentives for private landowners) and nonpermanency of stored carbon could limit the ability of agricultural carbon sequestration to contribute to international policy goals.

Several papers have examined the potential of carbon sequestration in forests and agricultural soils. Olschewski and Benitez (2005), for example, investigate the impact of Kyoto 
Protocol accounting rules related to temporary vs. long-term certified emission reductions. They conclude that assigning temporary credits, although excluded from accepted clean development mechanisms (CDM) for carbon sink projects during the first commitment period of the Kyoto protocol, could induce environmentally beneficial secondary afforestation in Ecuador for relatively small prices per ton of $\mathrm{CO}_{2}$ (Olschewski and Benitez 2005, p. 380). Wilman (2011) finds that higher offset payments are needed to reduce tillage frequency and thereby increase longer-term carbon sequestration rates on agricultural soils.

McCarl and Sands (2007) use economy-wide models to analyze a suite of alternatives designed to mitigate GHG emissions through agricultural and forestry management. They conclude that agricultural and forestry management alternatives can provide an important short-term bridge to more longrun solutions to stabilize atmospheric GHG concentrations. They warn, however, that such strategies will likely play a limited role in the future. The above mentioned literature highlights the potential for carbon sequestration on agricultural soils given different management practices and alternative benefit streams; however, it also highlights issues associated with length and uncertainty of storage associated with agricultural soil carbon sinks.

While there is a growing literature on the economics of carbon sequestration in forest and agricultural soils, Ritten et al. (2009) and McCarl et al. (2002) note a paucity of research specifically related to the economic consequences of rangeland sequestration. They both conclude with a call for more research on the firm-level benefits and costs associated with carbon sequestration on agricultural lands, with Ritten et al. (2009) more heavily stressing the need for such research on range livestock production systems. We briefly examine developments in the carbon market and then simulate potential revenue streams for rangeland managers. Specifically, we evaluate the revenue streams from enrolling in a voluntary carbon market patterned after the Chicago Climate Exchange (CCX) Rangeland Soil Carbon Offset program. Although the parameters of our simulation model are consistent with the CCX program, the issues modeled are relevant to understanding the potential for range managers to adopt management practices that improve carbon sequestration on rangelands worldwide given existing voluntary carbon market exchanges. We also examine the impacts of potential increases in $\mathrm{CO}_{2}$ prices under various cap-and-trade projections to determine if this sort of legislation is likely to encourage more producer participation. Finally, to more accurately model internationally recognized requirements, we extend the contract life to $100 \mathrm{yr}$-the length likely needed for offsets to be traded under a cap-and-trade system that meets Intergovernmental Panel on Climate Change (IPCC) recommendations.

\section{CARBON MARKET DEVELOPMENT}

Relatively recent events have provided rangeland managers with potential revenues from carbon sequestration. Markets for $\mathrm{CO}_{2}$ emission offsets emerged slowly in the 1980s and 1990s (Brand and Meizlish 2007) but became more prevalent in the early 2000s after the 1997 Kyoto Conference and resulting
Kyoto Protocol (Hansjürgens 2005). Kyoto Protocol established emission reduction targets for signatory countries and provided specific instruments and language related to implementation, including emissions trading, which provided guidelines for voluntary and mandatory carbon emission trading markets (Hansjürgens 2005).

While a number of countries signed the Kyoto Protocol, members of the European Union (EU) are seemingly the only countries to have effectively implemented a cap-and-trade system. In this type of system, $\mathrm{CO}_{2}$ or $\mathrm{CO}_{2}$ equivalent $\mathrm{GHG}$ emissions are capped at a particular level, and all firms regulated under the cap-and-trade system are allotted permits or rights to emit (Hansjürgens 2005). Firms that adopt abatement technology or undertake approved CDM projects to reduce their overall GHG emissions generate offset credits, which they can sell to firms that emit more than their allotment (Ellerman et al. 2010). Each year, a firm must meet its allotted amount of emissions or purchase credits for overages. Over time the maximum amount of emissions or cap is reduced, thereby forcing firms to reduce emissions or pay higher prices to purchase additional credits. A result of the increase in the price of carbon credits is that more firms adopt pollution saving technologies, such as CDMs, or go out of business, either of which results in a reduction in overall emissions. It is important to note that in the European Trading Scheme (ETS), the firms trade for emissions that were saved in the same year.

Many countries not involved with the ETS system have seen increased interest in voluntary carbon markets to facilitate the trading of emissions permits. Several exchanges have evolved to allow voluntary trading of carbon credits in preparation for potential regulations and to offer a mechanism for interested firms to reduce their carbon footprint. The CCX was established in 2003, and other global affiliates followed, including the Montreal Climate Exchange (Canada), Tianjin Climate Exchange (China), the European Climate Exchange (which accounts for $80-90 \%$ of traded volume in the EU ETS), and EnVex (Australia).

All of the voluntary exchanges have a standardized contract representing 100 metric tons of $\mathrm{CO}_{2}$ equivalents. The contracts on the CCX, for example, are based on allowances issued to exchange members in accordance with their emission baseline and reduction schedule. Offsets are generated by qualifying offset projects similar in duration to temporary emission reduction certificates (e.g., Olschewski and Benitez 2005). During 2005 to 2009, the offsets program included participation by more than 15000 farmers, ranchers, and foresters who conducted mitigation practices on more than 25 million acres of land. According to Gosnell et al. (2011), this included approximately 1000 ranches and over 2 million ha enrolled in the Rangeland Soil Carbon program. Trading volume on the CCX peaked in $2008^{1}$ but slowed dramatically following the global financial crises. While the voluntary cap and trade program offered through the CCX expired at the end of 2010, the CCX is still a functioning registry for the over-the-counter (OTC) carbon credit market (Peters-Stanley et al. 2011). Likewise, one of the nation's largest aggregators of rangeland

\footnotetext{
Daily trading averaged 284925 metric tons per trading day in 2008, with a high of 3864300 metric tons traded on March 4, 2008. The highest price observed to date was $\$ 7.40$ per ton $\mathrm{CO}_{2}$ on 2 June 2008.
} 
acres, the North Dakota Farmers Union (NDFU), has ceased enrolling new acres in the program due to the recent drop off in prices; however, they state that they will continue to monitor the opportunities associated with carbon sequestration for their members (NDFU 2012). Therefore, even though current prices do not encourage market participation, the market infrastructure is in place should the demand for voluntary offsets increase. According to Peters-Stanley et al. (2011), many current suppliers are cautiously optimistic about increasing demand for OTC credits as the economy rebounds.

The existence of voluntary exchanges provide agricultural producers, including rangeland managers, a potential market opportunity to sequester carbon even in the face of many countries choosing not to follow the ETS cap-and-trade example, which do not recognize sequestration from the majority of agroforestry projects. The short-term nature of the offsets generated on voluntary markets, however, does not generally meet international standards. Given the lifespan of GHGs in the atmosphere (see Forster et al. 2007; Meehl et al. 2007), current guidelines suggest $100 \mathrm{yr}$ of terrestrial carbon storage is necessary to offset 1 metric ton of $\mathrm{CO}_{2}$ (Smith et al. 2007). Thus, rangeland carbon sequestration projects are unlikely to ever meet CDM standards under a rigorous capand-trade system.

Given the current political and economic climate in the United States, it seems likely that incentives from voluntary carbon markets, while not in compliance with IPCC objectives, are the most likely near-term source of revenue associated with carbon sequestration for rangeland managers. Thus, a relevant question becomes whether the level of revenues from voluntary carbon market sources provides incentives that might change grazing land management. Alternatively, if a cap-and-trade system were adopted and offset projects were required to sequester carbon for a 100-yr period given IPCC guidelines, another relevant question would be whether that would provide incentives to range managers that would be more or less attractive than voluntary carbon markets.

\section{ECONOMIC ISSUES FOR RANGELAND CARBON SEQUESTRATION}

Several issues affect the firm- or farm-level economic viability of enrolling rangeland management practices in voluntary carbon markets. Three of the biggest issues, the cost of management practices, revenue variability, and market/contract structure, are addressed below. These three issues can impact the profitability of carbon contracts specifically by reducing the incentives for participation in carbon markets. These issues are likely to have an impact on the number of producers willing to participate in voluntary carbon markets or provide long-term offset projects under a potential cap-and-trade system.

\section{Cost of Management Practices}

Best management practices for cropland carbon sequestration and the economic consequences of those practices are the subject of a growing literature (e.g., Antle et al. 2001a, 2001b, 2002a, 2002b). Relatively little research exists, however, on best practices for rangeland carbon sequestration. Research suggests there are several management practices that can improve the amount of carbon sequestered on rangelands, including adjusting stocking rates, interseeding alfalfa, burning, fertilizing, and restoring degraded pastures (Schuman et al. 2002; Mortenson et al. 2004; Woomer et al. 2004; Derner and Schuman 2007).

Although existing research indentifies potential management strategies, it provides little information about the firm-level costs of adopting such practices. Campbell et al. (2004) investigate the costs of storing carbon on Wyoming rangelands by interseeding falcata alfalfa, using mineral or water placement to improve rangeland utilization, and thinning sagebrush. They conclude rangeland carbon sequestration could potentially compete on a cost-basis with sequestration from crop or forest lands, with costs (i.e., decreased revenues) of sequestration ranging from $\$ 12$ to $\$ 60 \cdot \mathrm{ha}^{-1}$. Since market data were inaccessible for sequestered carbon at the time of their research, the economic viability of rangeland management practices could not be fully evaluated.

\section{Revenue Variability}

Many agricultural commodities exhibit variability in revenue across years. In the case of traditional commodities, revenue variability results from variability in yields and prices. Several issues may cause similar variability in revenues from rangeland carbon sequestration.

Actual carbon yields from rangeland management practices can vary annually depending on management practices and weather conditions. However, due to the structure of the shortterm voluntary contracts, such as those under the CCX and its global affiliates, producers are credited at a fixed rate per year, with the only real yield variability coming in years of drought or fire, which result in no credits being earned for that year.

Revenue streams from rangeland carbon sequestration in voluntary carbon markets with short term contracts or markets under a proposed cap-and-trade system (potentially with spot or forward delivery) will also vary due to price fluctuations associated with supply and demand for emissions contracts. Carbon credit prices on the CCX, for example, have fluctuated significantly since its inception (Fig. 1). The price variability inherent to trading markets implies that rangeland managers will not be able to predict with certainty the return from participating in a carbon market. It also implies that the net returns to rangeland sequestration could be zero or negative if credit prices are sufficiently low. Moreover, if long-term offset projects of $100 \mathrm{yr}$ are required, the risks associated with soil carbon release and price variability multiply. Rangeland landowners will therefore have to accept some level of risk to participate in sequestration markets.

\section{Contract Structure}

Revenue potential of rangeland carbon sequestration is highly dependent on the specific characteristics of the contracts (e.g., duration and specific obligations) required to participate in carbon markets. In the United States, landowners can participate in voluntary carbon markets, such as the CCX, by contracting to provide $\mathrm{CO}_{2}$ offset credits using approved rangeland management practices. Individual offset contracts require a 5 -yr commitment and assume constant expected $\mathrm{CO}_{2}$ "yields" given management practices and location. Per the CCX 


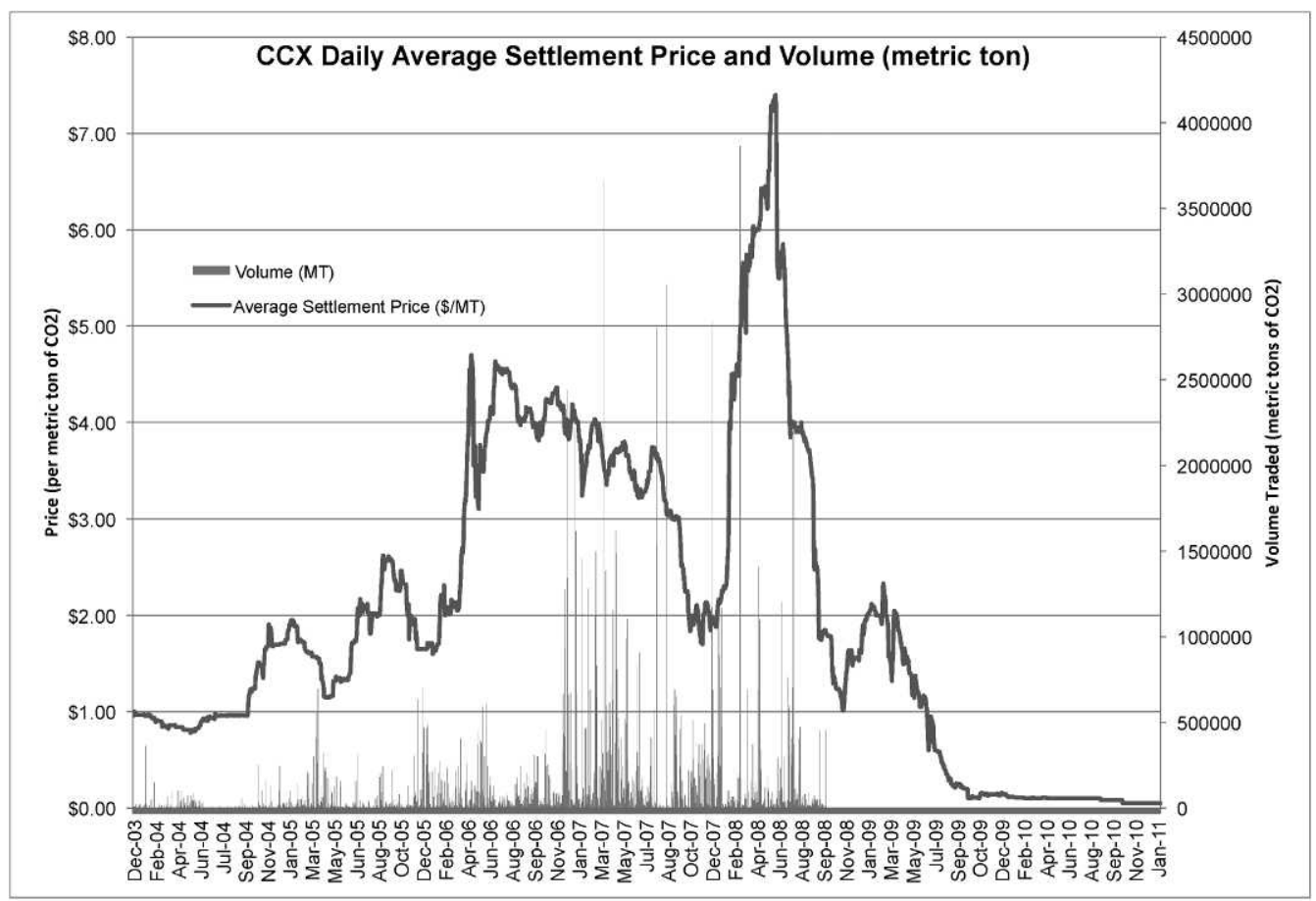

Figure 1. Historical carbon prices per credit (ton $\mathrm{CO}_{2} \mathrm{e}$ ) (2005 vintage) and trading volume. Source: http://theccx.com/market/data/summary.jsf

Rangeland Soil Carbon program, yields for nondegraded rangelands range from 0.30 to 0.67 metric tons of $\mathrm{CO}_{2} \cdot \mathrm{ha}^{-1} \cdot \mathrm{yr}^{-1}$ (CCX 2009b). Yields on degraded rangelands are slightly higher at the outset, because rehabilitation sequesters additional carbon.

CCX contracts address "yield" variability by requiring $20 \%$ of the contract credits be retained until the end of the contract. This reserve pool implies that contract participants only receive annual revenues on $80 \%$ of their sequestered $\mathrm{CO}_{2}$ in the year it was physically captured. If participants alter their management practices or face exogenous factors (e.g., drought) that reduce carbon yield, participants may forego payments on the $20 \%$ reserve pool. This reserve pool is held until the end of the contractual period and is used to off-set any decrease in carbon storage or increase in carbon losses, eliminating the need for a producer to repay for any decrease in stored carbon. If the producer is able to fulfill the contract without experiencing any of these events, they will receive payment for the entirety of their reserve pool at the completion of the contract. However, the price of the reserve pool will be based on the market price at the end of the contract, not the price at the time the $\mathrm{CO}_{2}$ was stored. Although the reserve pool approach is not a true insurance mechanism (i.e., risk is not diversified), it likely captures some of the compliance/insurance costs producers would face in any voluntary offset program.

Contract structure can also impose additional costs on rangeland managers who want to participate in carbon markets. Rules of the CCX, for example, require that offset projects involving less than 10000 metric tons of $\mathrm{CO}_{2}$ per year be registered through an offset aggregator (CCX 2010). Given the minimum quantity on each CCX contract (100 metric tons of $\mathrm{CO}_{2}$ ) and the total offset project requirement of 10000 metric tons of $\mathrm{CO}_{2}$, private rangeland managers are typically unable to fill the total offset requirement on their own. As such, offset aggregators (market intermediaries) facilitate individual participation in CCX contracts by reducing transactions costs through aggregating carbon sequestration across multiple individuals for a fee (Menkhaus et al. 2004; Lipper et al. 2010). Aggregator fees are usually between $8 \%$ and $10 \%$ of the value of carbon credits traded (Ribera et al. 2009). Moreover, enrollees trading through an aggregator are also responsible for paying registration and trading fees of $\$ 0.15$ and $\$ 0.05$ per credit, respectively (Ribera et al. 2009), and verification fees, which vary across aggregators (AgraGate 2009; Ribera et al. 2009).

\section{METHODS}

We determined potential firm-level revenues of participation in a short-term voluntary offset program by modeling the CCX Rangeland Soil Carbon Offset program during 2005-2009. The CCX offset contracts allow carbon credit trading for carbon sequestered on rangelands in certain US Department of Agriculture Land Resource Regions (CCX 2009b; Fig. 2). Eligible lands are all located in the western United States, with carbon credit rates varying by region. We estimate potential revenue streams for each region by analyzing a sample 5-yr contract. In the sample contract, we assume carbon yield is constant according to region, and therefore we do not explicitly model yield variability. The remaining characteristics of our sample contract are consistent with CCX contracts (Table 1).

The rangeland carbon sequestration contracts offered through the CCX are 5-yr commitments, with fixed per-hectare carbon credits accruing to land based on geographic location in the western United States (Table 2). Compliance with contract 


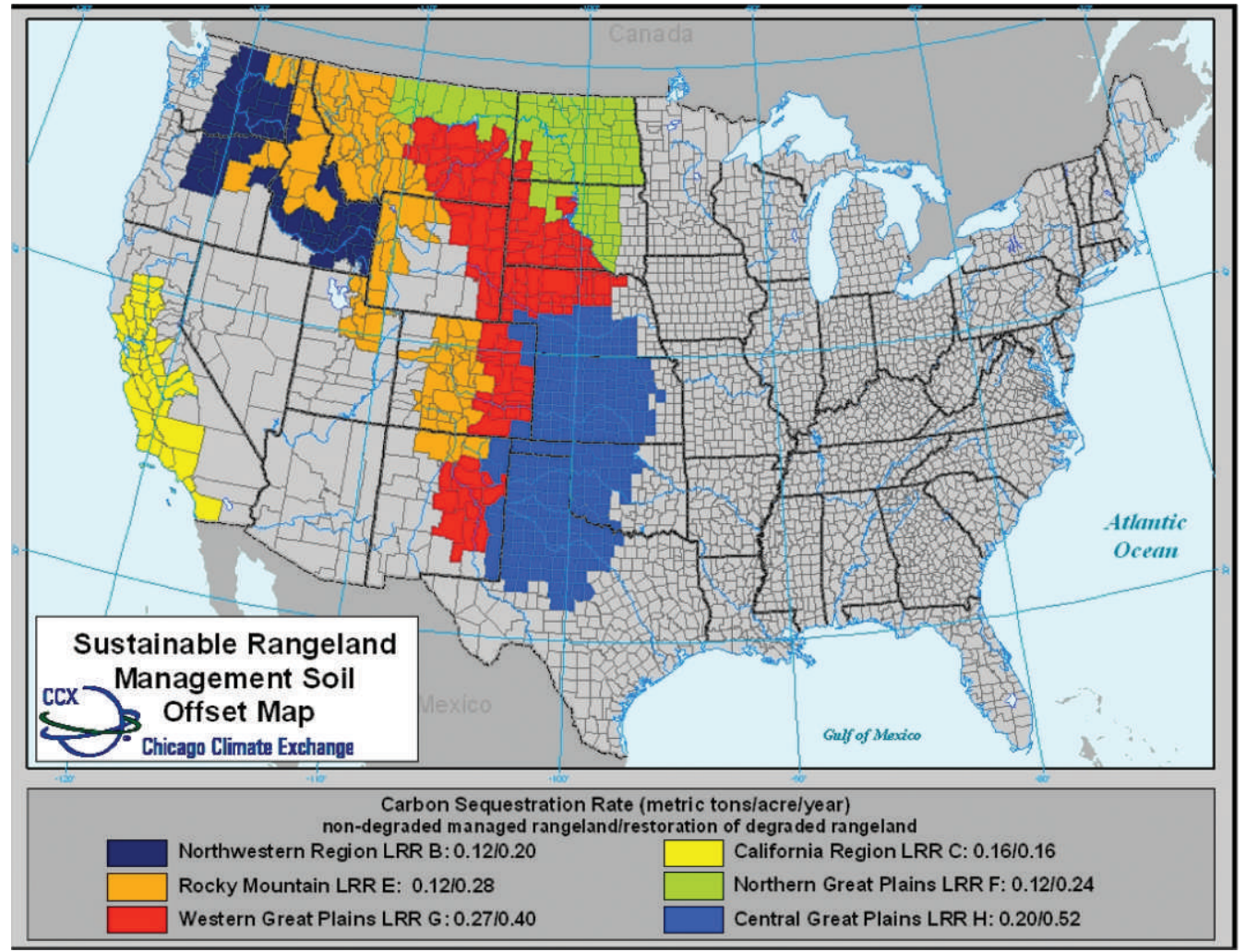

Figure 2. Lands eligible for Rangeland Management Carbon Offset Program. Source: http://www.agragate.com/docs/RangelandCreditRateMap.jpg

requirements is validated through a CCX verification processes. During the period analyzed, any ranch consisting of at least 12140 ha are verified in the initial year to ensure program requirements are being met. Ten percent of all other ranches are verified in the first year of a contract. Ten percent of all ranches are verified in the subsequent $4 \mathrm{yr}$ of the contract.

Unless a producer is able to generate 10000 metric tons of $\mathrm{CO}_{2}$ equivalents annually, they are required to use an aggregator to gain market access. Aggregators pool credits from numerous sources to meet the minimum trading requirements. However, aggregators charge for their services reducing the overall payments received by producers. Land managers also lose control of trading decisions when using an aggregator, as timing of sales decisions are made by the aggregator.

Our sample contract included all fees required to trade on the CCX. We assumed an aggregator fee equal to $10 \%$ of gross annual revenues, a flat verification fee of $\$ 0.25 \cdot \mathrm{ha}^{-1}$, and a

Table 1. Parameters used to estimate returns to rangeland carbon offset contracts.

\begin{tabular}{ll}
\hline Parameter & \multicolumn{1}{c}{ Value } \\
\hline Aggregator fee & $10 \%$ of value of $\mathrm{CO}_{2}$ traded \\
Verification fee & $\$ 0.25 \cdot \mathrm{ha}^{-1}$ \\
Trading fee $^{1}$ & $\$ 0.20 \mathrm{per}^{\text {credit }^{1}}$ \\
Reserve pool $^{1}$ & $20 \%$ \\
\hline
\end{tabular}

${ }^{1}$ Reserve pool is the proportion of offset credits $\left(1\right.$ credit $=1$ ton $\left.\mathrm{CO}_{2} \mathrm{e}\right)$ withheld until the final contract year. trading fee of $\$ 0.20$ per credit, all of which are consistent with reported contracts (AgraGate 2009; Ribera et al. 2009). Consistent with the CCX reserve pool requirements, we assumed $20 \%$ of annually earned credits are withheld each year to be sold at the end of the contract period. We deflated revenues and costs realized in different years of the contract. To assure our results are not overly sensitive to the assumed discount rate, we deflated using a $2 \%, 7 \%$, and $12 \%$ real discount rate. We also model a contract in which all credits are sold in the year they accrue (i.e., no reserve pool requirement) to determine the impact of the reserve pool on return variability.

Appendix 1 shows an example, using parameters for the Western Great Plains region, of how we calculated offset contract value in year 1 based on average 2005 prices, accounting for the reserve pool requirement. Of the 0.67 carbon credits earned per hectare per year, 0.13 credits are held back in the reserve pool, leaving 0.54 credits to be traded in the

Table 2. Carbon credit sequestration rate per hectare per year by geographic region.

\begin{tabular}{lc}
\hline \multicolumn{1}{c}{ Land resource region } & $\begin{array}{c}\text { Carbon } \text { credit }^{1} \\
\text { rate }\left(\text { credit } \cdot \text { ha }^{-1} \text { ) }\right.\end{array}$ \\
\hline Northwest, Rocky Mountain, and Northern Great Plains & 0.3 \\
California & 0.4 \\
Central Great Plains & 0.49 \\
Western Great Plains & 0.67 \\
\hline
\end{tabular}

${ }^{1} \mathrm{~A}$ carbon credit is defined as 1 ton of $\mathrm{CO}_{2} \mathrm{e}$. 
Table 3. Distribution of carbon credit prices by vintage. ${ }^{1}$

\begin{tabular}{|c|c|c|c|c|c|}
\hline & 2005 & 2006 & 2007 & 2008 & 2009 \\
\hline \multicolumn{6}{|l|}{ Vintage } \\
\hline Average annual price per credit $^{2}$ in vintage year & $\$ 1.77$ & $\$ 3.56$ & $\$ 3.19$ & $\$ 3.74$ & $\$ 1.13$ \\
\hline Low annual price per credit in vintage year & $\$ 1.10$ & $\$ 1.65$ & $\$ 1.70$ & $\$ 1.00$ & $\$ 0.10$ \\
\hline High annual price in per credit vintage year & $\$ 2.48$ & $\$ 4.75$ & $\$ 4.20$ & $\$ 7.40$ & $\$ 2.35$ \\
\hline SD & $\$ 0.35$ & $\$ 0.96$ & $\$ 0.70$ & $\$ 1.90$ & $\$ 0.72$ \\
\hline \multicolumn{6}{|l|}{2009 prices by vintage ${ }^{3}$} \\
\hline Average price per credit in 2009 & $\$ 1.13$ & $\$ 1.13$ & $\$ 1.12$ & $\$ 1.12$ & $\$ 1.13$ \\
\hline Low vintage price per credit in 2009 & $\$ 0.10$ & $\$ 0.10$ & $\$ 0.10$ & $\$ 0.10$ & $\$ 0.10$ \\
\hline High vintage price per credit in 2009 & $\$ 2.35$ & $\$ 2.35$ & $\$ 2.30$ & $\$ 2.30$ & $\$ 2.35$ \\
\hline SD of prices in 2009 & $\$ 0.72$ & $\$ 0.72$ & $\$ 0.72$ & $\$ 0.72$ & $\$ 0.72$ \\
\hline
\end{tabular}

${ }^{1}$ Source: http://theccx.com/market/data/summary.jsf

${ }^{2} \mathrm{~A}$ carbon credit is defined as 1 ton of $\mathrm{CO}_{2} \mathrm{e}$.

${ }^{3} 2009$ prices by vintage are included to be used to price the reserve pool credits at the termination of the contract.

first year. The average carbon price for our first year of simulation was $\$ 1.77$ per credit, resulting in $\$ 0.95 \cdot \mathrm{ha}^{-1}$ in revenues. However, producers are required to pay aggregator fees $(\$ 0.09)$, verification $(\$ 0.25)$, and trading fees $(\$ 0.11)$, for a net annual return of $\$ 0.50 \cdot \mathrm{ha}^{-1}$. The 0.13 credits held in the reserve pool are sold in year 5 upon successful completion of the commitment but are sold at year 5 prices. Over our 5 -yr price analysis, the average final year price was only $\$ 1.13$ per credit, resulting in revenues of $\$ 0.15 \cdot \mathrm{ha}^{-1}$. However, producers are required to pay the aggregator fees and trading fees (\$0.015 and $\$ 0.03$, respectively) from those revenues for a net income of $\$ 0.11 \cdot \mathrm{ha}^{-1}$ in the final year of the contract. The total payment for the first year's sequestration is $\$ 0.61$, with $\$ 0.50$ being paid in year 1 , and $\$ 0.11$ being paid in year 5 . Similar calculations are made in each of the first $4 \mathrm{yr}$ of the contract. In the final year of the contract, all credits are paid for, as no credits are held in reserve. The result is a stream of revenues that can be discounted to determine the net-present value.

As noted earlier, the price of carbon credits can vary considerably (Fig. 1). As carbon is sold by vintage (i.e., year sequestered), carbon sequestered in 2005 was not necessarily sold the following year for the same price as carbon physically stored in 2006. Table 3 shows the distribution of carbon prices by vintage, as well as each vintage's price in $2009 .^{2}$ Given price variation, it is unlikely that a producer would receive the average annual price for their carbon credits each year. We therefore used a Monte Carlo simulation with 1000 draws from a distribution of annual carbon prices to account for price variability. We estimated distributions for each vintage based on CCX prices during the period from 2005 to 2009, which was the most recent complete 5 -yr period available (CCX 2009a). However, to assure the distribution does not include negative carbon prices, we used a log-normal transformation of prices in the Monte Carlo simulation. We assumed all carbon is sold once each year, with all reserve credits being sold in the final year of the contract. ${ }^{3}$ For each simulation, we summarized contract performance by calculating annual payments per hectare, total contract payments per hectare, and the net

\footnotetext{
${ }^{2}$ We include each vintages price in 2009 as $20 \%$ of annual carbon credits are held until the end of the contract and sold at 2009 prices.

${ }^{3}$ Number and timing of payments are determined by the aggregator and may be different than our assumptions.
}

present value (NPV) per hectare over the contract life. We also calculated each measure by region to account for spatial heterogeneity in carbon yield.

We also analyzed potential effects of pending cap-and-trade legislation on future revenue streams for short-term voluntary offset contracts. For prices under cap-and-trade legislation, we used the highest and lowest forecasted prices from a study conducted by American Electric Power (AEP 2004). The lowest forecast, based on the Carper Bill, predicts $\mathrm{CO}_{2}$ prices increasing to $\$ 6$ per ton by 2020 , while the highest forecast, based on the McCain-Lieberman Bill, predicts prices increasing to $\$ 37$ per ton. ${ }^{4}$ We also estimated a scenario using the mean ( $\$ 21.50$ per credit) of these two extreme forecasts. This price range encompasses recent prices observed for the EU European Climate Exchange September 2011 futures contract of $\$ 12$ to $\$ 13$ per ton and is consistent with other studies examining the impact of alternative carbon caps on $\mathrm{CO}_{2}$ prices in the United States (Tol 2005; Paltsev et al. 2007; Stavins 2008a, 2008b).

Lastly, given that short-term voluntary contracts are unlikely to meet international standards, we considered a simple longterm offset contract. Specifically, we used the highest forecasted $\mathrm{CO}_{2}$ price (i.e., McCain-Lieberman Bill) to estimate returns to a hypothetical 100-yr contract. Our 100-yr contract is essentially a bond; the value of the contract is determined by the regional sequestration rate and the offset price (i.e., \$37 per ton $\mathrm{CO}_{2}$ given the McCain-Lieberman Bill). We then assumed the contract value is placed in escrow for $100 \mathrm{yr}$, and grows at the rate of inflation (3.4\%; Bureau of Labor Statistics 2011). Finally, we determined the NPV of the offset contract using a discount rate of $5.7 \%$, which is consistent with current longterm bond rates (Federal Reserve System 2010). The result is an estimate of the current value of gross revenue from a long-term offset contract given the most optimistic price scenario. We do not account for any transactions costs, which are likely to be higher than the short-term contract case because the role of market intermediaries (i.e., aggregating, monitoring, insuring, and enforcing contracts) would be complex. We also ignore the very real possibility of drought or fire events over this time horizon, which would result in a decrease in actual storage and

\footnotetext{
${ }^{4}$ In the absence of any trading fees or transaction costs, these prices translate from $\$ 1.80$ to $\$ 4.02 \cdot \mathrm{ha}^{-1}$ for the Carper Bill and $\$ 11.11$ to $\$ 24.79 \cdot \mathrm{ha}^{-1}$ for the McCainLieberman Bill for the fixed sequestration rates approved by the CCX.
} 
Table 4. Simulated characteristics of rangeland carbon offset payments $\left(\$ \cdot \mathrm{ha}^{-1}\right)$ by land resource region given historical prices.

\begin{tabular}{|c|c|c|c|c|c|c|c|}
\hline & \multicolumn{5}{|c|}{ Annual payment per ha } & \multirow{2}{*}{$\begin{array}{l}\text { Average annual } \\
\text { payment per ha }\end{array}$} & \multirow[b]{2}{*}{$\mathrm{NPV}^{1}$ per ha } \\
\hline & 2005 & 2006 & 2007 & 2008 & 2009 & & \\
\hline \multicolumn{8}{|c|}{ Northwest, Rocky Mountain, and } \\
\hline \multicolumn{8}{|c|}{ Northern Great Plains (credit rate $=0.30)^{2}$} \\
\hline Mean & $\$ 0.10$ & $\$ 0.47$ & $\$ 0.40$ & $\$ 0.52$ & $\$ 0.32$ & $\$ 0.37$ & $\$ 1.46$ \\
\hline SD & $\$ 0.07$ & $\$ 0.27$ & $\$ 0.17$ & $\$ 0.52$ & $\$ 0.67$ & $\$ 0.17$ & $\$ 0.69$ \\
\hline Minimum & $\$ 0.00$ & $\$ 0.00$ & $\$ 0.00$ & $\$ 0.00$ & $\$ 0.00$ & $\$ 0.10$ & $\$ 0.42$ \\
\hline Maximum & $\$ 0.47$ & $\$ 1.70$ & $\$ 1.11$ & $\$ 5.58$ & $\$ 11.93$ & $\$ 2.62$ & $\$ 9.44$ \\
\hline \multicolumn{8}{|c|}{ California (credit rate $=0.40$ ) } \\
\hline Mean & $\$ 0.20$ & $\$ 0.69$ & $\$ 0.59$ & $\$ 0.79$ & $\$ 0.52$ & $\$ 0.57$ & $\$ 2.25$ \\
\hline SD & $\$ 0.10$ & $\$ 0.35$ & $\$ 0.22$ & $\$ 0.67$ & $\$ 0.86$ & $\$ 0.22$ & $\$ 0.86$ \\
\hline Minimum & $\$ 0.00$ & $\$ 0.00$ & $\$ 0.10$ & $\$ 0.00$ & $\$ 0.00$ & $\$ 0.12$ & $\$ 0.49$ \\
\hline Maximum & $\$ 0.79$ & $\$ 2.22$ & $\$ 1.46$ & $\$ 5.88$ & $\$ 9.56$ & $\$ 2.47$ & $\$ 9.16$ \\
\hline \multicolumn{8}{|c|}{ Central Great Plains (credit rate $=0.49$ ) } \\
\hline Mean & $\$ 0.30$ & $\$ 0.94$ & $\$ 0.82$ & $\$ 1.01$ & $\$ 0.67$ & $\$ 0.74$ & $\$ 3.01$ \\
\hline SD & $\$ 0.12$ & $\$ 0.42$ & $\$ 0.30$ & $\$ 0.86$ & $\$ 1.24$ & $\$ 0.32$ & $\$ 1.19$ \\
\hline Minimum & $\$ 0.00$ & $\$ 0.12$ & $\$ 0.20$ & $\$ 0.00$ & $\$ 0.00$ & $\$ 0.20$ & $\$ 0.86$ \\
\hline Maximum & $\$ 0.89$ & $\$ 3.63$ & $\$ 2.07$ & $\$ 7.48$ & $\$ 13.59$ & $\$ 3.21$ & $\$ 12.15$ \\
\hline \multicolumn{8}{|c|}{ Western Great Plains (credit rate $=0.67$ ) } \\
\hline Mean & $\$ 0.49$ & $\$ 1.33$ & $\$ 1.19$ & $\$ 1.48$ & $\$ 0.96$ & $\$ 1.09$ & $\$ 4.42$ \\
\hline SD & $\$ 0.17$ & $\$ 0.57$ & $\$ 0.37$ & $\$ 1.14$ & $\$ 1.61$ & $\$ 0.42$ & $\$ 1.53$ \\
\hline Minimum & $\$ 0.10$ & $\$ 0.20$ & $\$ 0.35$ & $\$ 0.00$ & $\$ 0.00$ & $\$ 0.44$ & $\$ 1.88$ \\
\hline Maximum & $\$ 1.19$ & $\$ 3.71$ & $\$ 3.21$ & $\$ 8.40$ & $\$ 19.04$ & $\$ 4.79$ & $\$ 17.59$ \\
\hline
\end{tabular}

${ }^{1} \mathrm{NPV}$ is the net present value per hectare of carbon payments assuming a $7 \%$ discount rate.

${ }^{2}$ Credit rate is the amount of carbon (in metric tons) sequestered per hectare per year, based on the Chicago Climate Exchange contract specifications.

potential release of storage. Thus, our value estimates for longterm contracts represent the most optimistic estimates.

\section{RESULTS}

Results from the 1000 simulations using historical prices indicate a relatively wide range of modest revenues across eligible regions from short-term voluntary contracts (Table 4). Average annual payment rates range from a low of $\$ 0.10 \cdot \mathrm{ha}^{-1}$ (Northwest, Rocky Mountain, and Northern Great Plains regions) to a high of $\$ 4.79 \cdot \mathrm{ha}^{-1}$ (Western Great Plains). Differences across regions are driven by the differences in carbon credit rates. The regions with the lowest carbon credit rate (Northwest, Rocky Mountain, and Northern Great Plains regions) recorded NPV for a 5-yr contract ranging from $\$ 0.42$ to $\$ 9.44 \cdot \mathrm{ha}^{-1}$, averaging only $\$ 1.46 \cdot \mathrm{ha}^{-1}$. For perspective, annual returns to livestock grazing in the Rocky Mountain region typically range from $\$ 27$ to $\$ 50 \cdot \mathrm{ha}^{-1}$ (Ritten et al. 2010 ), while the range of average annual carbon payments over a 5 -yr contract for this region is only $\$ 0.10$ to $\$ 2.62 \cdot \mathrm{ha}^{-1}$. The NPV for a 5 -yr carbon contract for the California region ranges between $\$ 0.49$ and $\$ 9.16 \cdot \mathrm{ha}^{-1}$, with an average of $\$ 2.25 \cdot \mathrm{ha}^{-1}$ for our simulation. In contrast, NPV over the contract life in the most productive region (Western Great Plains) ranges from $\$ 1.88$ to $\$ 17.59 \cdot \mathrm{ha}^{-1}$, with an average of $\$ 4.42 \cdot \mathrm{ha}^{-1}$. These average revenues are well below $\$ 12$ to $\$ 60 \cdot \mathrm{ha}^{-1}$ sequestration costs estimated by Campbell et al. (2004).

The revenue results for short-term contracts are, however, slightly sensitive to assumptions about the discount rate (see Appendix 2). The difference between the lowest $(2 \%)$ and highest $(12 \%)$ discount rates considered implies ranges of NPV estimates of $\$ 0.40$ to $\$ 1.30$. Thus, for example, the difference between the NPV of offset contracts in the Western Great Plains region with a discount rate of $2 \%$ vs. $12 \%$ is $\$ 1.30$. Though small in absolute terms, the differences between NPVs for alternative discount rates average approximately $30 \%$ of the contract value.

The simulation results over historical prices also highlight the variability in potential returns to rangeland carbon sequestration. In every region, for example, there were observations of zero annual payments. Thus, in some price scenarios the revenue from carbon credits was not sufficient to offset the costs of participating in the market. This suggests that rangeland managers could actually lose money (accounting for the costs of rangeland management) in some years of the contract. The variability in annual returns implies significant variability in the NPV of participating in carbon offset markets (Fig. 3). Moreover, the regions with the lowest credit rates also tend to have the highest relative variability in returns. The coefficient of variation (SD/mean) on the NPV, for example, is 0.47 in the Northwest, Rocky Mountain, and Northern Great Plains region and is 0.39 in the Western region. Thus, regions with low returns also tend to have higher variation in returns.

Revenues from short-term contracts are also influenced by contract structure. If there were no reserve pool requirement, for example, the average NPV from contracts would increase by $18 \%$ to $24 \%$ across regions. Removing the reserve pool requirement also reduces the standard deviation of the NPV by $1 \%$ to $12 \%$. Thus, requiring that $20 \%$ of contract credits be 


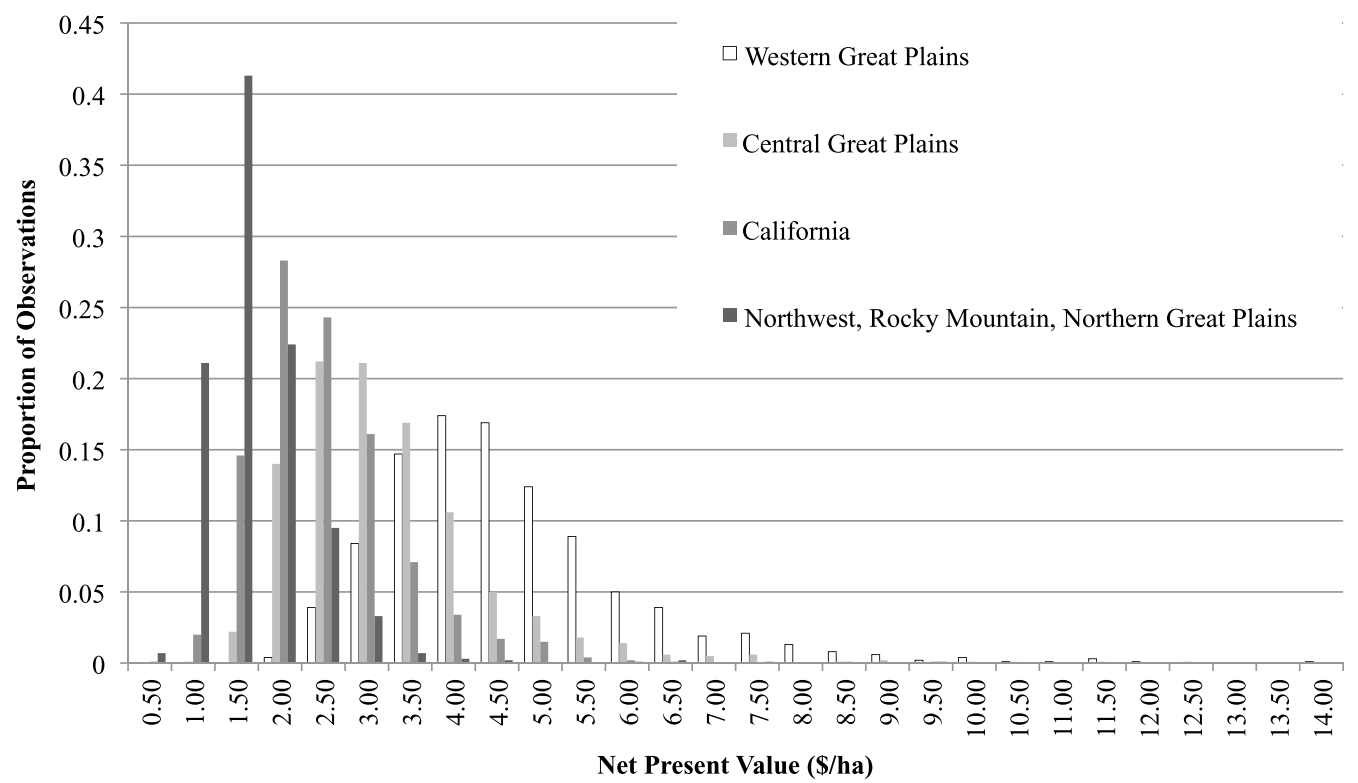

Figure 3. Distribution of simulated net present values per hectare of rangeland carbon sequestration contracts by eligible US Department of Agriculture Land Resource Regions.

held until the final year of the contract decreases revenues and increases revenue variability.

Results from the future price scenarios suggest cap-and-trade legislation could significantly increase the revenue streams to rangeland carbon offsets if the projected prices are applied to 5 yr contracts (Table 5). The low price projection (Carper Bill) more than doubles the NPV from a 5-yr carbon contract compared to the average NPV based on historical prices. Alternatively, if the result of cap-and-trade legislation were consistent with the projections of the McCain-Lieberman Bill, the potential attractiveness of sequestering carbon on rangeland is significantly increased. Results suggest NPV for a 5-yr contract given the high price scenario could range from $\$ 38.16$ to $\$ 64.27 \cdot \mathrm{ha}^{-1}$, depending on the region. Given typical returns to livestock grazing on rangelands, carbon payments of this magnitude are competitive with existing enterprises and might have the potential to impact producer's rangeland management decisions.

Alternatively, if we assume the projected cap-and-trade prices will only apply to $100-\mathrm{yr}$ offset projects, the returns are substantially less attractive (Table 5). Results from the 100yr payout for the most optimistic price scenarios (i.e., McCain-
Lieberman Bill in the Western Great Plains region) results in offset project NPV of $\$ 2.67$. The NPV of these long-term offset estimates are similar in magnitude to the short-term estimates; however, our long-term estimates do not account for any transactions or management costs.

\section{DISCUSSION}

The small per-hectare stream of revenues for short-term rangeland sequestration contracts given historical prices is not likely to encourage many producers to adopt the practices required to be eligible for program enrollment. These potential revenues would only be attractive if the chosen carbon management strategy also improved returns to the livestock enterprise. Campbell et al. (2004) indicate that interseeding with falcata alfalfa (Medicago stavia ssp. Falcata) and sagebrush thinning both increase carrying capacity and carbon storage, but the added costs reduced the NPV profits per hectare by $\$ 111.42$ and $\$ 64.07$ over a 20 -yr period, respectively. Our simulated returns from CCX contracts would not overcome the added costs indicated in Campbell et al. (2004) even given the differences in time frames.

Table 5. Comparison of net present values (NPVs; $\$ \cdot$ ha $^{-1}$ ) of short-term offset projects by land resource region for alternative carbon prices with pending cap-and-trade legislation for both current Chicago Climate Exchange (CCX) standards and a 100-yr offset requirement.

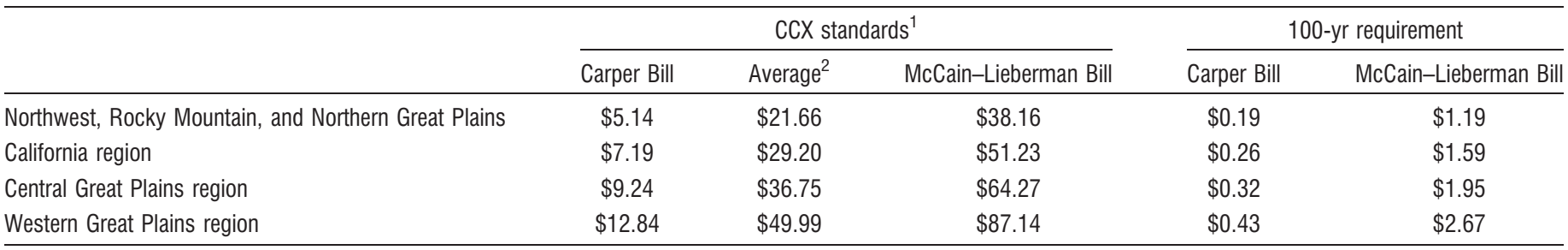

${ }^{1}$ Historical estimates are the average NPVs calculated using a Monte-Carlo simulation using a price distribution consistent with carbon credit prices from 2005 to 2009 on the CCX.

${ }^{2}$ Average assumes carbon credit prices are the mean between prices projected under the Carper Bill and prices projected under the McCain-Lieberman Bill. 
Appendix 1. Example return calculation for Chicago Climate Exchange (CCX)-based rangeland carbon offset contract in the Western Great Plains region, including annual and total contract performance of example CCXbased rangeland carbon offset 5-yr contract.

\begin{tabular}{lr}
\hline Sequestration rate $\left(\right.$ tons $\left.\mathrm{CO}_{2} \cdot \mathrm{ha}^{-1}\right)$ & 0.67 \\
Less reserve pool $(20 \%)$ & 0.13 \\
Total credits traded in year 1 & 0.54 \\
Initial year carbon price $\left(\$ \cdot\right.$ ton $\left.^{-1}\right)$ & $\$ 1.77$ \\
Revenues $\left(\$ \cdot\right.$ ha $\left.^{-1}\right)$ & $\$ 0.95$ \\
Fees & \\
$\quad$ Aggregator fee $\left(10 \%\right.$ of revenues) $\left.^{-1}\right)$ & $\$ 0.09$ \\
$\quad$ Verification fee $\left(\$ 0.25 \cdot\right.$ ha $\left.^{-1}\right)$ & $\$ 0.25$ \\
Trading cost $\left(\$ 0.20 \cdot\right.$ credit $\left.^{-1}\right)$ & $\$ 0.11$ \\
Total fees & $\$ 0.45$ \\
Annual net income per ha (year 1$)$ & $\$ 0.50$ \\
$\quad$ Credits held over in reserve pool per ha & 0.13 \\
$\quad$ Final year price $\left(\$ \cdot\right.$ ton $\left.^{-1}\right)$ & $\$ 1.13$ \\
Revenues from reserve pool in year $5\left(\$ \cdot\right.$ ha $\left.^{-1}\right)$ & $\$ 0.15$ \\
Fees & \\
$\quad$ Aggregator fee $(10 \%)$ & $\$ 0.02$ \\
$\quad$ Trading cost $\left(\$ 0.20 \cdot\right.$ credit $\left.^{-1}\right)$ & $\$ 0.03$ \\
Total fees & $\$ 0.04$ \\
Annual net income per ha (end of contract) & $\$ 0.11$ \\
Total net income per ha for the initial year & $\$ 0.61$ \\
\hline
\end{tabular}

${ }^{1} \mathrm{NPV}$ is the net present value per hectare of carbon payments assuming a $7 \%$ discount rate.

If cap-and-trade legislation is implemented but 100 -yr projects are required for certified emissions reductions, incentives for producers to adopt carbon storing management practices are only slightly improved. Even with higher carbon prices, the profit margins for entering long-term contracts are likely to be slim at best. Given the costs from Campbell et al. (2004), it is not likely that range producers will find management alternatives to increase carbon sequestration on rangelands very attractive given the revenue potential available.

An additional concern with managing for SOC is the potential risk associated with contract structure (i.e., price variability) or weather events that reduce overall carbon sequestration (i.e., yield variability). The current reserve requirement of the US voluntary market increases the risk that producers will receive a relatively low carbon price for a large number of their sequestration credits. This problem is exacerbated for long-term contracts. Alternatively, what if producers found themselves in a drought situation that caused the net exchange of carbon on their land to transition from being a carbon sink to being a carbon source? It is not clear whether there is enough monitoring and enforcement with current short-term voluntary contracts to catch such transitions, nor is it clear what the consequences would be if monitoring and enforcement were sufficient. Again, this problem is exacerbated for rangeland managers and market intermediaries trying to provide contracts to rangeland producers if a cap-and-trade system required 100-yr contracts. Risks such as these are likely to dramatically reduce the incentives to manage rangelands for SOC. Moreover, current IPCC guidelines do not suggest that $100-\mathrm{yr}$ projects on range would be accepted as CDMs. Thus, a number of issues would seemingly need to be overcome for range projects to be allowed
Appendix 2. Net present value of short-term rangeland carbon offset contracts for alternative discount rates across eligible land resource regions.

\begin{tabular}{lccc}
\hline & \multicolumn{3}{c}{ Discount rate } \\
\cline { 2 - 4 } \multicolumn{1}{c}{ Land resource region } & $2 \%$ & $7 \%$ & $12 \%$ \\
\hline Northwest, Rocky Mountain, and Northern Great Plains & $\$ 1.68$ & $\$ 1.46$ & $\$ 1.28$ \\
California & $\$ 2.67$ & $\$ 2.25$ & $\$ 1.96$ \\
Central Great Plains & $\$ 3.51$ & $\$ 3.01$ & $\$ 2.69$ \\
Western Great Plains & $\$ 5.11$ & $\$ 4.42$ & $\$ 3.81$ \\
\hline
\end{tabular}

as offset credits for a cap-and-trade system adhering to IPCC recommendations.

The United States does not appear likely to uphold Kyoto or other international standards in the near future. Thus, shortterm voluntary contracts aimed at reducing agriculture's carbon footprint may be as likely as any other offset program available to rangeland managers. If short-term incentives were attractive enough to alter range manager's practices or invest in alternatives conducive to increased sequestration, environmentally positive benefits related to GHG emissions could be made. Yet, even the short-term contracts appear generally insufficient to incentivize rangeland managers without significant increases in offset prices.

\section{IMPLICATIONS}

It seems unlikely that many private managers would find recent incentives to sequester carbon sufficient. Also, the requirement of annual reserve pool that is held until the completion of the current short-term voluntary contracts adversely impacts results of our model contract by decreasing mean returns and increasing return variability. Our analysis suggests producer enrollment in this type of program may be more attractive if prices increase dramatically, as might be seen under cap-andtrade legislation, but a number of issues arise regarding risks and acceptability of range projects if IPCC recommendations are followed. Research on methods to reduce management and transactions costs, and to reduce risks of participation (e.g., using private insurance markets) could improve the feasibility of rangeland carbon markets. However, some producers may still be unlikely to participate in carbon markets. Hatfield et al. (2009) state that many ranchers express skepticism about climate change and that decisions are generally made on an annual basis in regard to economic survivorship. Cheatum et al. (2011) suggest that emphasis on the cobenefits of carbon programs, such as improved wildlife habitat, may be needed in order to encourage participation. Moreover, Cheatum et al. (2011) suggest that administration of the program is also important to participation, with nonprofit organizations being the preferred administrator, with state-run programs requiring additional premiums to encourage at least some ranchers to participate. However, Gosnell et al. (2011) state that the majority of ranchers they spoke with suggest that the Natural Resource Conservation Service would be the most logical program administrator. Clearly, many issues need to be addressed before we can expect large-scale adoption of carbon sequestration practices on US rangelands. 


\section{LITERATURE CITED}

AgraGate. 2009. AgraGate climate credits corporation carbon credit program, exchange soil offset contract. Available at: http://www.kfb.org/naturalresources/ nrimages/SoilOffsetContract.pdf. Accessed 9 August 2009.

[AEP] American Electric Power. 2004. An assessment of AEP's actions to mitigate the economic impacts of emissions policies. Columbus, OH, USA: American Electric Power. 118 p.

Antle, J., S. Capalbo, E. Elliot, W. Hunt, S. Mooney, and K. Paustian. 2002a. Research needs for understanding and predicting the behavior of managed ecosystems: lessons from agroecosystem research. Ecosystems 4(8):723-735.

Antle, J., S. Capalbo, S. Mooney, E. Elloot, and K. Paustian. 2001a. Economic Analysis of agricultural soil carbon sequestration: an integrated assessment approach. Journal of Agricultural and Resource Economics 26(2):344-367.

Antle, J., S. Capalbo, S. Mooney, E. Elliot, and K. Paustian. 2001b. Sensitivity of carbon sequestration costs to soil carbon rates. Environmental Pollution 116(3):413422.

Antle, J., S. Capalbo, S. Mooney, E. Elliot, and K. Paustian. 2002b. A comparative examination of the efficiency of sequestering carbon in US agricultural soils. American Journal of Alternative Agriculture 17(3):109-115.

Brand, D., and M. MeizLISH. 2007. An investor's perspective on the voluntary carbon market. In: R. Bayon, A. Hawn, and K. Hamilton [EDS.]. London, UK: Earthscan. p. 87-90.

Bureau OF LaboR Statistics. 2011. Table of monthly consumer price index (CPI), and annual estimates of CPI from 1914 to 2011. Available at: http://www. usinflationcalculator.com/category/inflation-rates/. Accessed 1 August 2011.

Campbell, S., S. Mooney, J. P. Hewlett, D. J. Menkhaus, and G. F. Vance. 2004. Can ranchers slow climate change? Rangelands 26(4):16-22.

[CCX] Chicago Climate Exchange. 2009a. CCX CFI market data charting tool. Available at: http://theccX.com/market/data/summary.jsf. Accessed 1 July 2010.

CCX. 2009b. Chicago Climate Exchange sustainably managed rangeland soil carbon sequestration offset project protocol. Available at: http://theccx.com/docs/offsets/ CCX_Sustainably_Managed_Rangeland_Soil_Carbon_Sequestration_Final.pdf. Accessed 1 July 2010.

CCX. 2010. Membership guidelines. Available at: http://theccX.com/content. jsf?id=65. Accessed 18 October 2010.

Cheatum, F., P. Alvarez, and B. Parkhurst. 2011. Payments for ecosystem services: a California rancher perspective. Conservation Economics White Paper. Conservation Economics and Finance Program. Washington, DC, USA: Defenders of Wildlife. $65 \mathrm{p}$.

Derner, J. D., and G. E. Schuman. 2007. Carbon sequestration and rangelands: a synthesis of land management and precipitation effects. Journal of Soil and Water Conservation 62(2):77-85.

Ellerman, A. D., F. J. Convery, and C. De Perthuis. 2010. Pricing carbon: the European Union Emissions Trading Scheme. New York, NY, USA: Cambridge University Press. 390 p.

Federal Reserve System. 2010. H15, selected interest rates. Available at: http://www. federalreserve.gov/releases/h15/data.htm. Accessed 1 August 2011.

Feng, H., J. ZhaO, AND C. L. KLing. 2002. The time path and implementation of carbon sequestration. American Journal of Agricultural Economics 84(1):134-149.

Follett, R. F., J. M. Kimble, and R. Lal. 2001. The potential of US grazing lands to sequester soil carbon. In: R. F. Follett, J. M. Kimble, and R. Lal [EDS.]. The potential of US grazing lands to sequester carbon and mitigate the greenhouse effect. Boca Raton, FL, USA: Lewis Publishers. p. 401-430.

Follett, R. F., And D. A. Reed. 2010. Soil carbon sequestration in grazing lands: societal benefits and policy implications. Rangeland Ecology \& Management 63:4-15.

Forster, P., V. Ramaswamy, P. Artaxo, T. Berntsen, R. Betts, D. W. Fahey, J. Haywood, J. Lean, D. C. Lowe, G. Myhre, J. Nganga, R. Prinn, G. Raga, M. Schulz, and R. VAN DoRLAND. 2007. Changes in atmospheric constituents and in radiative forcing. In: S. Solomon, D. Qin, M. Manning, Z. Chen, M. Marquis, K. B. Averyt, M. Tignor, and H. L. Miller [EDS.]. Climate change 2007: the physical science basis. Contribution of Working Group I to the Fourth Assessment Report of the Intergovernmental Panel on Climate Change. Cambridge, UK, and New York, NY, USA: Cambridge University Press. p. 129-234.
Gosnell, H., N. Robinson-Maness, and S. Charnley. 2011. Engaging ranchers in marketbased approaches to climate change mitigation: opportunities, challenges, and policy implications. Rangelands 33(5):20-24.

HansuÜRGENS, B. 2005. Introduction. In: B. Hansjürgens [ED.]. Emissions trading for climate policy: US and European perspectives. New York, NY, USA: Cambridge University Press. p. 1-14.

Hatfield, J., D. Batie, J. Holzfaster, M. Kelly, and R. Koelsch. 2009. Integrating crop, livestock and irrigation technologies to ensure food security and environmental quality. Lincoln, NE, USA: Office of Research and Economic DevelopmentPublications, University of Nebraska-Lincoln. Paper 6. Available at: http:// digitalcommons.unl.edu/researchecondev/6. Accessed 22 February 2012.

Laca, E. A., M. McEachern, and M. W. Demment. 2010. Global grazing lands and greenhouse gas fluxes. Rangeland Ecology \& Management 63:1-3.

LiPPER, L., C. Dutlitity-Diane, and N. McCarthy. 2010. Supplying carbon sequestration from West African rangelands: opportunities and barriers. Rangeland Ecology \& Management 63:155-166.

McCarl, B. A., B. Murray, and J. Antle. 2002. Agricultural soil carbon sequestration: economic issues and research needs. College Station, TX, USA: Department of Agricultural Economics, Texas A\&M University. Draft Paper \#875. 85 p.

McCarL, B. A., AND R. SANDS. 2007. Competitiveness of terrestrial greenhouse gas offsets: are they a bridge to the future? Climatic Change 80:109-126.

Meenl, G. A., T. F. Stocker, W. D. Collins, P. Friedlingstein, A. T. Gaye, J. M. Gregory, A. Kitoh, R. Knutti, J. M. Murphy, A. Noda, S. C. B. Raper, I. G. Watterson, A. J. WeAVer, And Z.-C. ZHAo. 2007. Global climate projections. In: S. Solomon, D. Qin, M. Manning, Z. Chen, M. Marquis, K. B. Averyt, M. Tignor, and H. L. Miller [EDs.]. Climate change 2007: the physical science basis. Contribution of Working Group I to the Fourth Assessment Report of the Intergovernmental Panel on Climate Change. Cambridge, UK, and New York, NY, USA: Cambridge University Press. 747-845.

Menkhaus, D. J., A. Yakunina, and P. J. Herz. 2004. Food retailing in the Russian federation and implications for the food supply chain. Journal of East-West Business 10(3):53-73.

Mortenson, M. C., G. E. Schuman, and L. J. Ingram. 2004. Carbon sequestration in rangelands interseeded with yellow-flowering alfalfa (medicago sativa ssp. falcata). Environmental Management 33(Supplement):S475-S481.

[NDFU] North Dakota Farmers UnIon. 2012. Welcome to the famers union carbon credit program. Available at: http://carboncredit.ndfu.org/. Accessed: 22 February 2012.

Olschewski, R., And P. C. Benitez. 2005. Secondary forests as temporary carbon sinks? The economic impact of accounting methods on reforestation projects in the tropics. Ecological Economics 55:380-394.

Paltsev, S. J. M., H. Rellly, D. Jacoby, A. C. Gurgel, G. E. Metcalf, A. P. Sokolov, and J. F. HoLAK. 2007. Assessment of U.S. cap-and-trade Proposals. Cambridge, MA, USA: National Bureau of Economic Research. Working Paper 13176. 66. p.

Peters-Stanley, M., K. Hamilton, T. Marcello, and M. Suardin. 2011. Back to the future: state of the voluntary carbon markets 2011. Washington, DC, USA: Ecosystem Marketplace \& Bloomberg New Energy Finance. 79 p.

Ribera, L. A., B. A. McCarl, and J. Zenteno. 2009. Carbon sequestration: a potential source of income for farmers. Journal of the American Society of Farm Managers and Rural Appraisers 72(1):70-77.

Ritten, J. P., C. T. Bastian, B. S. Rashford, J. Norton, U. Norton, S. I. Paisley, and P. Burgener. 2009. Can carbon find a home on the range? Western Economics Forum 8(2):14-20.

Ritten, J. P., W. M. Frasier, C. T. Bastian, and S. T. Gray. 2010. Optimal rangeland stocking decisions under stochastic and climate-impacted weather. American Journal of Agricultural Economics 92(4):1242-1255.

Schuman, G. E., H. H. Janzen, and J. E. HerRick. 2002. Soil carbon dynamics and potential carbon sequestration by rangelands. Environmental Pollution 116(3):391-396.

Smith, P., D. Martino, Z. Cal, D. Gwary, H. Janzen, P. Kumar, B. McCarl, S. Ogle, F. O'Mara, C. Rice, B. Scholes, and 0. Sirotenko. 2007. Agriculture. In: B. Metz, O. R. Davidson, P. R. Bosch, R. Dave, and L. A. Meyer [EDs.]. Climate change 2007: mitigation. Contribution of Working Group III to the Fourth Assessment Report of the Intergovernmental Panel on Climate Change. Cambridge, UK, and New York, NY, USA: Cambridge University Press. 
Sobecki, T. M., D. L. Moffitt, J. Stone, C. D. Franks, and A. G. Mendenhall. 2001. A broad-scale perspective on the extent, distribution, and characteristics of US grazing lands. In R. F. Follett, J. M. Kimble, and R. Lal [EDS.]. The potential of US grazing lands to sequester carbon and mitigate the greenhouse effect. Boca Raton, FL, USA: Lewis Publishers. p. 21-63.

Stavins, R. N. 2008a. A meaningful U.S. cap-and-trade system to address climate change. Fondazione Eni Enrico Mattei Working Papers. Working Paper 241. Available at: http://www.bepress.com/feem/paper241. Accessed 17 May 2012.
Stavins, R. N. 2008b. Addressing climate change with a comprehensive cap-andtrade system. The Oxford Review of Economic Policy 24(2):298-321.

ToL, R. S. J. 2005. The marginal damage costs of carbon dioxide emissions: an assessment of the uncertainties. Energy Policy 33(16):2064-2074.

WiLman, E. A. 2011. Carbon sequestration in agricultural soils. Journal of Agricultural and Resource Economics 36(1):121-138.

Woomer, P. L., A. Tourè, and M. Sall. 2004. Carbon stocks in Senegal's Sahel transition zone. Journal of Arid Environment 59:499-510. 